\title{
Three Coptic Potsherds from the Cairo Museum
}

Sohair S. Ahmed

Faculty of Arts, Egyptology Department, Ain Shams University, Egypt

Sohair_ahmed2002@yahoo.com

\begin{abstract}
This paper presents three Coptic potsherds kept in the Cairo Egyptian Museum - as part of a collection of Coptic ostraca bearing the special registration number 18953.

The first ostracon represents a private letter, the sender's name is missing here suggested to be Joseph and the recipient seems to be a monk his name is Mosses; this letter was sent concerning giving dates to a shepherd called Anaias.

The second and the third ostraca are parts from agreement for repayment a loan and perhaps they represent one text.

In the second potsherd, the names of debtor and creditor are missing in the text, the loan was one (or more) of golden coin called Tremis. The repayment will be in something lost in the text perhaps money or cereals. The repayment will be with interest.

The third potsherd represents the assent formula of an agreement for repayment a loan (perhaps represents the end of the last text), it represents the signature of the debtor who is a deacon and calledPashtosh.
\end{abstract}

Key Words: Ostraca, potsherd, Coptic, Tremis, shepherd, monk, deacon.

\section{ثلاثة قطع فخار من المتحف المصري}

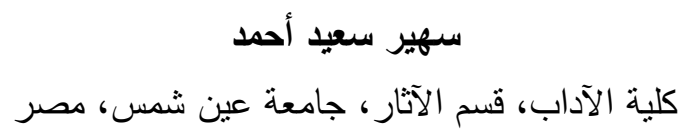

Sohair_ahmed2002@yahoo.com

$$
\begin{aligned}
& \text { الملخص: يقدم هذا البحث نشر ثلاثة أوستراكا عبارة عن قطع فخارية ذات لون بني وأحمر مكتوبة بالقبطية }
\end{aligned}
$$

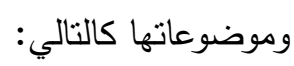

$$
\begin{aligned}
& \text { القطعة الأولى: تمنل خطاب شخصي مرسل إلى راهب (؟) يدعى موسى بثأن استلام المرسل لشيء ما مفقود في } \\
& \text { النص (يقترح إنه بلح) نم إعطاؤه أو دفعه إلى راعي الخراف المسئ التهى أناياس. }
\end{aligned}
$$

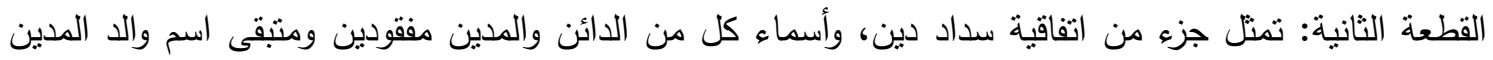

$$
\begin{aligned}
& \text { ويسمى "باني" والدين هنا هو العملة الذهبية تريمسيون ويتضح من النص أن السداد كان سيتم مع دفع فائدة. }
\end{aligned}
$$

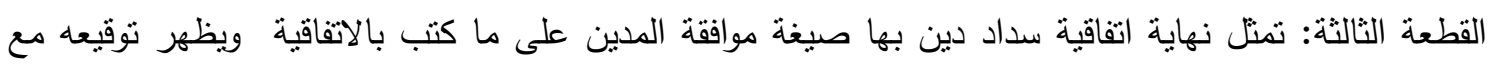

$$
\begin{aligned}
& \text { ذكر اسمه ولقبه ويقترح أنها تمثل نفس النص المكتوب على القطعة الثانية والمدين هنا يسمى باشتوش وهو شماس } \\
& \text { ويُقترح تأريخ النصوص من القرون السادس إلى الثامن الميلاديين. } \\
& \text { الكلمات الدالة: أوستركا، قطع فخارية، القبطية، تريميسيون، راعي الخراف، راهب، شمناس. }
\end{aligned}
$$


This paper presents three unpublished Coptic ostraca written on potsherds kept in the Cairo Egyptian Museum - as part of a collection of Coptic ostraca, lacking any information about its provenance(s) or date(s) and bearing the special registration number 18953.

The first ostracon represents a private letter, while the second and the third ostraca are parts from an agreement for repayment a loan and perhaps they represent one text. It is remarkable that the Copts preferred to write the private and administrative letters on potsherds while they prefer limestone chips in writing the ecclesiastical letters. As for the contracts and agreements, they preferred to write it on potsherds because the pottery absorbs the ink so it became difficult to be erased and falsified. ${ }^{1}$

\section{The $1^{\text {st }}$ Ostracon}

SR no.: 18953

Inventory no.: 98

Dimensions: height $6 \times 4$ width $\mathrm{cm}$.

Excavator: Unknown

Provenance: Unknown.

Date: Unknown, suggested being from the $6^{\text {th }}-8^{\text {th }}$ century AD.

Description: The text is written in black ink on the outer part, remaining with about 8 lines. The writing is clear. The beginning and the end of the text is both missing.

Dialect: Sahidic (indicated by super linear strokes and the trema).

Content: A part from a letter, probably a private one. The sender's name is mostly missing, and the recipient seems to be a monk his name is Moses. The letter's subject concerns giving dates to a shepherd called Anaias.

\section{The text:}

\section{Recto}

+1 .[2NOK ïฒCH-]

2. $\phi[\Theta q C 2 d i \epsilon(u) I n \in]$

3. छாव̣[CON M(1)-]

4. $\bar{\gamma} \mathrm{CHC̣}[\mathrm{XE}]$

$$
\text { ' سهير أحمد، جوانب من الحياة اليومية للأقباط من النصوص والآثار القبطية (القاهرة: V . Y)، .9. }
$$




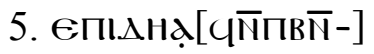

6. ne ndï аїв[ітCоY $\left.{ }^{1}\right]$

7. $\overline{\mathrm{NT}}$ TKTddC $[\overline{\mathrm{M}}]$

8. пManeç[OOY]

9.[d] naldẹ[

\section{Translation:}

1. [I Jose-]

2. ph?[ he writes (and) greets]

3.my[ brother Mo-]

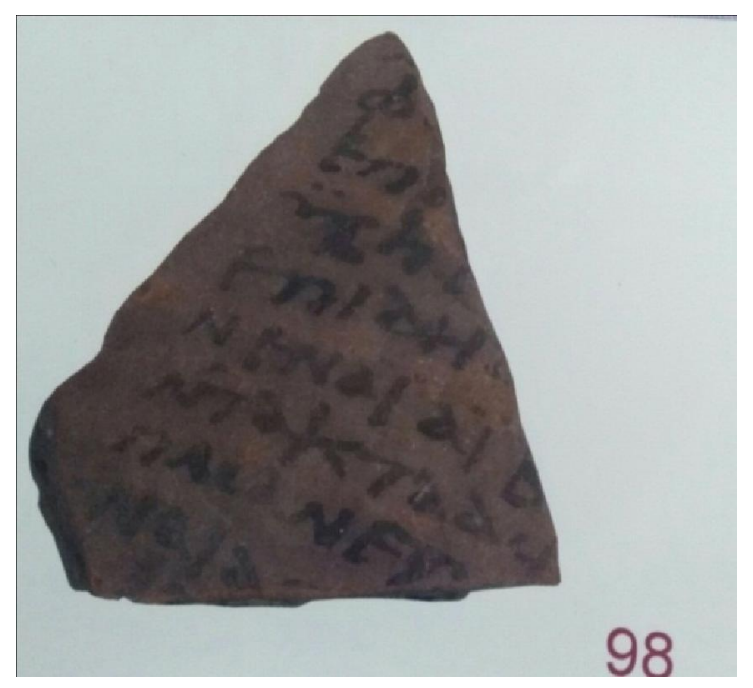

4. ses [

5. whereas [he brought the dates?]

6. to me, I to[okit]

7. until you give/pay it[to]

8. the pastor of [sheep]

9. Anias

\section{Comment:}

Line 1:ф: A part from a personal name suggested being ІшCHC "Joseph".

Line 5:Ne is suggested to be the noun Bत̄ne "dates" which is written in this form in Sahidic, Akhmimic and Sub-Akhmimic dialects. ${ }^{2}$

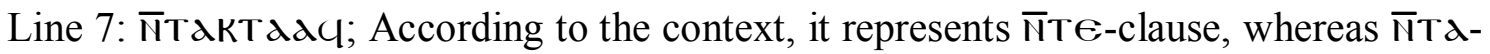
means here "to, so as to, until", it is mentioned in many Coptic loan formulas as: † $\mathrm{O}$ n2€TOIMOC NTdTddC NaK "I am ready to give/pay it to you". 3

Line 8:пmanecooY: Means the pastor of sheep or the shepherd later became (1)wC. ${ }^{4}$

Line 9: anide: A proper name ${ }^{5}$ from Hebrew, perhaps a short form of andNida, Ar. حنانيا.

${ }^{1}$ Cf: S. Ahmed, A Group of Unpublished Coptic Ostraca in the Cairo Museum, vol. I, no. 3 (Cairo: 2008), 17-20.

${ }^{2} \mathrm{CD}, 40 \mathrm{a}-\mathrm{b}$.

${ }^{3}$ The example from: OMH, no., 60.

${ }^{4}$ S. Ahmed, "Professions, Trades, Occupations and Titles in Coptic-Alphabetically", part I, JCopS12, 131, CD, 61a.

${ }^{5}$ Monika Hasitzka, Namen in Koptischen Dokumentarischen Texten, Part I (Wien: Österreichischen National bibliothek Papyrussammlung und Papyrusmuseum, 2006), 10 (PDF-book) 


\section{The $2^{\text {nd }}$ Ostracon}

SR no.: 18953

Inventory no.: 42

Dimensions: height $6 \times 5.6$ width $\mathrm{cm}$.

Excavator: Unknown

Provenance: Unknown

Date: Unknown, suggested being from the $6^{\text {th }}-8^{\text {th }}$ century AD.

Description: Parts from five regular lines written in black ink on the outer side of a red potsherd. The writing is clear, with lacunas on both right and left sides and at the end of the text.

Dialect: seems to be Sahidic with other influences.

Content: A part from a promise for repayment a loan. Names of the debtor and the creditor are missing in the text, only the father's name of the debtor remains. The loan was one or more of a golden coin called Tremision. The repayment was to be in something lost in the text, perhaps money or cereals, plus interest.

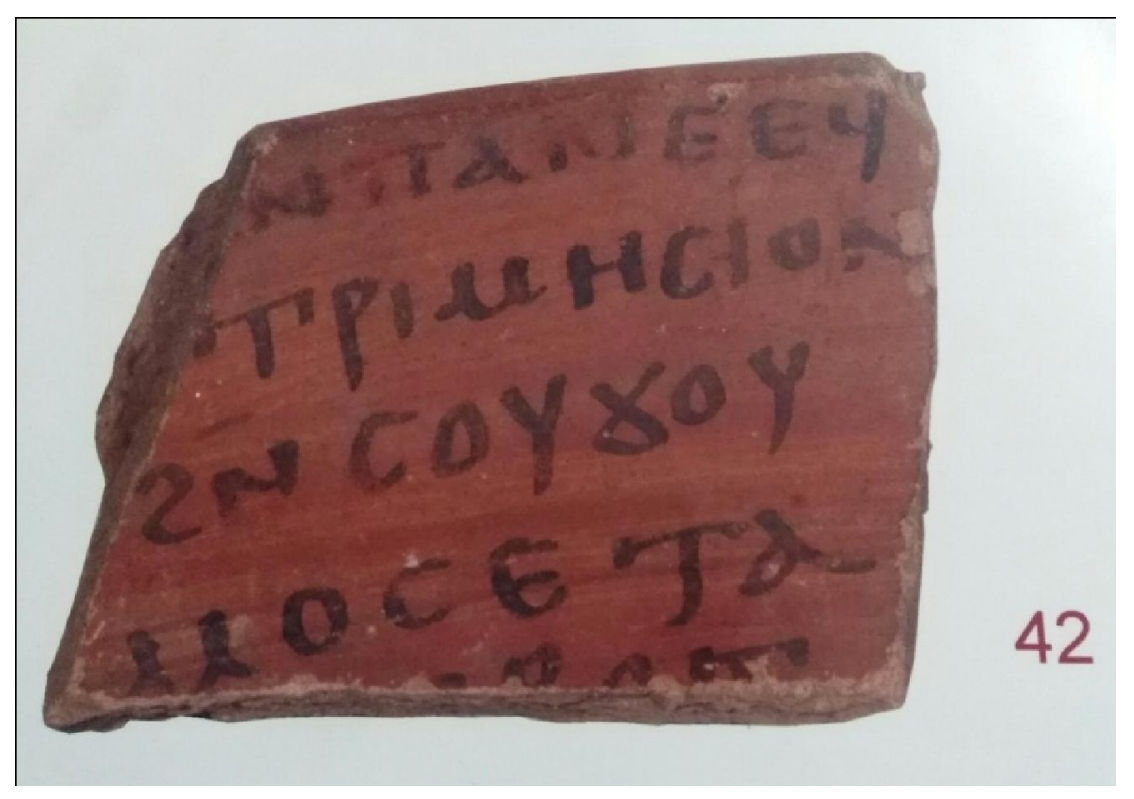

\section{Text:}

\section{Recto}

1. [anOK NN]n паNe $\epsilon_{4}\left[\mathrm{C}_{2} \alpha \mathrm{I} \overline{\mathrm{N}} \mathrm{NN} \overline{\mathrm{N}} \mathrm{NN}\right]$

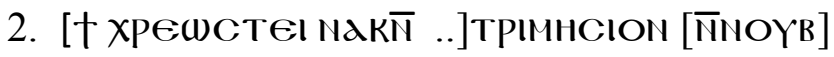

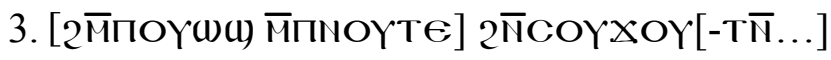

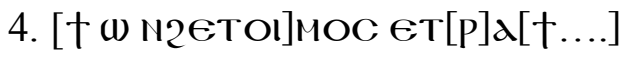

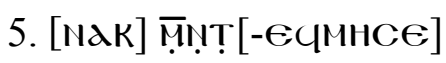




\section{Translation:}

1. [ INN son of] "Pane" he [writes to NN son of NN]

2. [I owe you (number/one)] tremis [of gold]

3. [by God willing] in the $20^{\text {th }}$ [ of (month -name)]

4. [I pre]pareto repay(something)]

5. [to you] with it[s interest]

\section{Comment:}

Line 1: Generally, the usual opening formula of the agreements for repayment loans consists of:

The names of both debtor and creditor, as:

aHOK A €T/€q/€їC2dï̄ B, sometimes also written are:

The names of their fathers, or the address of both (or of the creditor only), or adding sometimes the date ${ }^{1}$.

N ПגNE: It is remarkable that $\mathrm{N}$ was not assimilated to $\mathrm{M}$ before $\Pi$ which may refers to ME dialect and this matter never happened in Thebes ${ }^{2}$.

$\bar{\Pi}$ dNeis a proper name ${ }^{3}$.

Line 2: трімнсіON: A golden coin, its weight is $1.5 \mathrm{gm}$. And it is $1 / 3$ the holkottinos $(=\text { solidus })^{4}$.

Line 3: it represents the date of repayment which is usually written in one of several forms:

$1.2 \bar{M}-($ ПЕвот) month name.

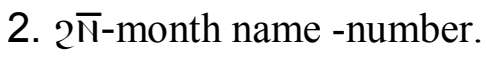

3. $2 \overline{\mathrm{N}}$-month name (number)-indiction.

4. $2 \overline{\mathrm{N}}$-monthname - under $\mathrm{NN}$ (son of $\mathrm{NN}$ ) the lashane.

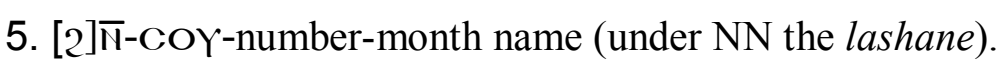

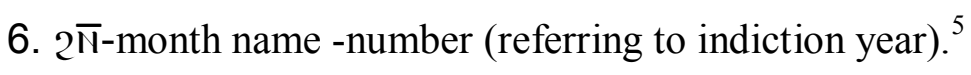

Line 4 and 5: the formula of repayment:

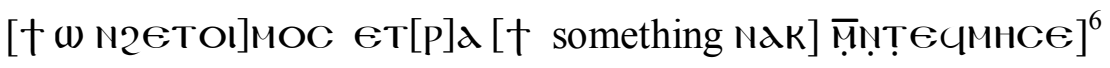

\footnotetext{
${ }^{1}$ Kopt.Ostraka I, 42

${ }^{2}$ Bal. I, 99-100

${ }^{3}$ Hasitzka, Monika, Namen, part II, 15.

${ }^{4} \mathrm{WB}, 820$

${ }^{5} \mathrm{OMH}$, no. 50-52, 56,59,60, 61,65

${ }^{6} \mathrm{Cf}$ : OMH, no. 60 .
} 
MHCE "usury, interest" from $m s$ "grain received as interest" In Demotic mst means "interest"1 replaced by ()(1) many times. ${ }^{2}$

\section{The $3^{\text {rd }}$ Ostracon}

SR no.: 18953

Inventory no.: 76

Dimensions: height $4 \times 7.5$ width $\mathrm{cm}$.

Excavator: Unknown

Provenance: Unknown

Date: Unknown, suggested being from the $6^{\text {th }}-8^{\text {th }}$ century AD.

Description: The text now comprises parts of two regular lines written in black ink on the inner side of a red potsherd. The script is clear with lacunas on both lift and top sides of the text.

Dialect: Difficult to be determined, the text being too short.

Content: Assent formula of a loan-repayment agreement (representing perhaps part of the last text). It consists of the signature of the debtor who is a deacon called Pashtosh.

This formula is usually followed by the signatures of the scribe and witnesses.

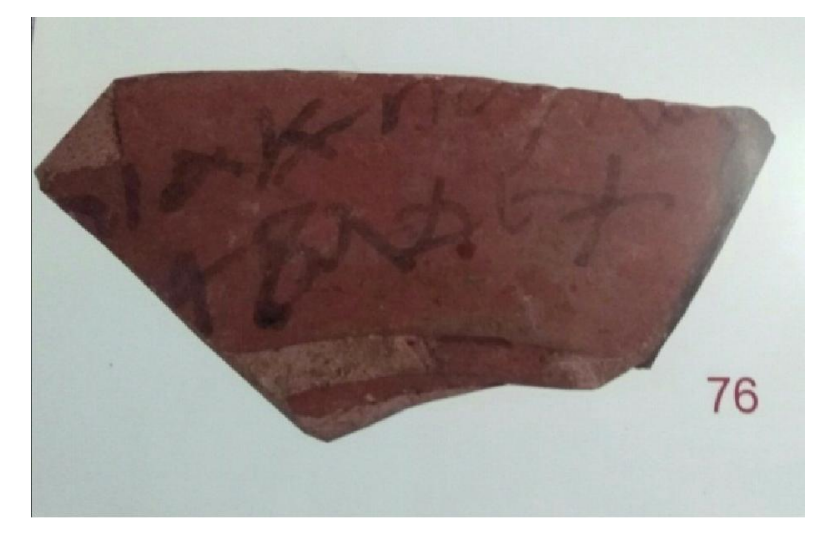

\section{The text:}

\section{Verso}

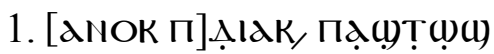

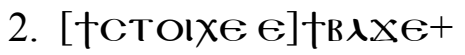

\footnotetext{
${ }^{1} \mathrm{CED}, 90$.

${ }^{2}$ Sohair Ahmed, "Two Coptic Legal Ostraca", in P. Buzi, A. Camplani\& F. Contradict, Coptic Society, in OLA (247), 1321.
} 


\section{Translation:}

1. [I the] deacon Pashtosh

2. [I assent to $]$ this sherd +[

\section{Comment:}

Line 1: П.ᄉldK/: An abbreviation for П.ᄉldKON "the deacon" common in the $7 / 8^{\text {th }}$ centuries AD. ${ }^{1}$

Пд()Т()(1): A Coptic personal name common as пג(l)TO(). ${ }^{2}$

Line 2: B $\lambda x \in$ in Sahidic and Akhmimic dialects, it means lit. "Pottery, potsherd" ${ }^{3}$, here it refers to the agreement. A ligature is between $€$ and the cross.

\section{Results:}

- Using the dates in paying the hires and repayment the loans.

- The debtor in Coptic texts can owe golden coins like solidus and Tremis.

- The repayment of loans can be with or without interest.

- The promise of repayment a loan was closing with the assent formula (as a signature of debtor) then the signature of scribe then the signature of witnesses.

\footnotetext{
${ }^{1} \mathrm{WB}, 181-182$.

${ }^{2}$ Hasitzka, Monika, Namen, part 2, 19.

${ }^{3} \mathrm{CD}, 38 \mathrm{~b}$
} 


\section{Bibliography:}

\section{1- Lexicons:}

- $\mathrm{CD}=$ W.E. Crum, ACoptic Dictionary, Oxford: 1939

- CED= J. Černy, Coptic Etymological Dictionary, Cambridge: 1976

- WB $=$ H. Förster, Wörterbuch der Griechischen Wörter in den Koptischen Dokumentarischen Texten, Berlin: 2002.

\section{2- Refrences:}

- OMH= E. Stefanski\& M. Lichtheim, Coptic Ostraca from MedinetHabu, Chicago: 1952.

- Kop. Ostraka I= A. Biedenkopf-Ziehner, Koptische Ostraka I, Wiesbaden: 2000

-Ahmed S., A Group of Unpublished Coptic Ostraca in the Cairo Museum, vol. I,Cairo: 2008.

- AhmedS., "Two Coptic Legal Ostraca", in P. Buzi, A. Camplani\& F. Contradict, Coptic Society, Literature and Religion from Late Antiquity to Modern Times, Proceedings of the $10^{\text {th }}$ International Congress of Coptic Studies, Rome, September 2012, 2 vols. in OLA (247), Peeters: Leuven-Paris-Bristol: 1317-1322

- AhmedS.,"Professions, Trades, Occupations and Titles in Coptic -Alphabetically", Part I, J CopS 12, Peeters; Leuven, Paris, Bristol (2010):115-148.

- Bal. I= P. Kahle, Coptic Texts from Deir el-Bala'izah in Upper Egypt I-II (London: Oxford University Press, 1954)

- Hasitzka, Namen in KoptischenDokumentarischenTexten, Parts I- II (Wien: ÖsterreichischenNationalbibliothekPapyrussammlung und Papyrusmuseum, 2006), (PDF-book)

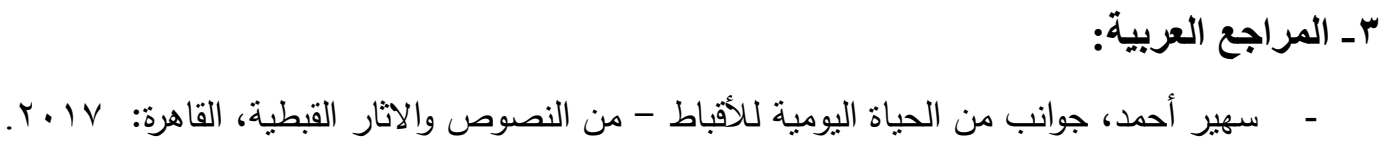

